\title{
IDAE framework: A guide for establishing industry-driven academic programs
}

\author{
Challiz D. Omorog \\ College of Computer Studies, Camarines Sur Polytechnic Colleges, Philippines
}

\begin{tabular}{|c|c|}
\hline Article Info & ABSTRACT \\
\hline Article history: & An empirical study using descriptive-quantitative methods was conducted to \\
\hline Received Sep 27, 2019 & $\begin{array}{l}\text { investigate this hypothesis and examine the appropriateness of the framework } \\
\text { components on the potential offering of an academic program at Camarines }\end{array}$ \\
\hline Revised Nov 26, 2019 & Sur Polytechnic Colleges (CSPC). The Identify, Determine, Assess and \\
\hline Accepted May 1, 2020 & $\begin{array}{l}\text { Establish (IDAE) model provided strategies and results essential for } \\
\text { institutional decision-making. The model also proposes that if at least one of }\end{array}$ \\
\hline Keywords: & $\begin{array}{l}\text { the components- I-D-A were not satisfied, the last component- E should not } \\
\text { be pursued. Simply put, the academic program should not be instituted. }\end{array}$ \\
\hline Curriculum developers & However, further research is encouraged to support these arguments. \\
\hline
\end{tabular}

Framework

Program development model

This is an open access article under the $\underline{C C B Y-S A}$ license.

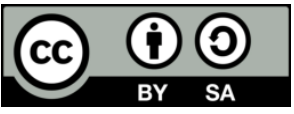

\section{Corresponding Author:}

Challiz D. Omorog,

College of Computer Studies,

Camarines Sur Polytechnic Colleges,

San Miguel, Nabua, Camarines Sur, 4434, Philippines.

Email: challizomorog@cspc.edu.ph

\section{INTRODUCTION}

The growing labor market mismatch in the Philippines continues to tinge the country's economic landscape [1]. As of April 2017 unemployment rate was estimated at 5.7 percent or 2.3 million individuals [2]. According to Montt, one underlying factor behind the high rate job-skill mismatch is education [3]. His study explains the reasons in two distinct concepts, (1) "qualification mismatch", which happens when individuals are formally educated in a particular field then downgrades to another field just to find work; and (2) "skills mismatch", which results from a technical or soft skills mismatch as against those required by the jobs. Thus, amid the many new employment opportunities, unemployment and underemployment remains high [4].

To subdue the growing economic threat, the Department of Labor and Employment (DOLE) in the Philippines initiated a project to generate updated labor market information [5]. This project called the "JobsFit: the DOLE 2020 Vision" was aimed to strengthen the private and public sector collaboration in addressing the job-skill mismatch. Results of the project identified that academic and training institutions appear to still offer irrelevant school curricula and training regulation competencies, which further aggravates the job-skill mismatch in the country. In order to address the job mismatch, the Philippine Education System (PES) in place the K to 12 Basic Education Curriculum approved as Republic Act 10533 on 2013. The K to 12 Curriculum aimed to improve the mastery of every young Juan Dela Cruz on basic, primary, secondary (junior high school), and post-secondary (senior high school) competencies. The Senior High School (SHS) program was fully implemented in 2016. 
The $\mathrm{K}$ to 12 Curriculum reform is a good start, however, not the solution. Orbeta et al. reveals that the culprit for the mishap in the supply and demand of jobs is the tertiary education sector [6]. Their study claims that higher education institutions (HEIs) failed its mandate to provide relevant manpower to the demands of the labor market and the consequences resulted in the mismatch. Other studies have directly examined the positive and negative role of education in employment that contributed to overeducation $[7,8]$. In the Philippines, of the 1, 943 HEIs in count [9], job mismatch is still massive. The implication of the labor employment mismatch heightened the call for HEIs to take immediate action. Thus, HEIs are encouraged to timely substantiate and formulate educational programs and trainings through interactive and collaborative approaches with the concerned stakeholders, such as the industry to stop the incidence of job-skill mismatch. Simply put, they must produce graduates with technical and discipline competencies aligned and required for employment. Otherwise, it could impact job satisfaction characterized by lower earnings and poorer job prospects [10].

However, academic program formulation and implementation is extravagant and iterative [11]. Initially, research must be conducted to determine if the academic program is relevant to societal needs, and feasible for future economic and social progress. This argument is further supported by the studies of [12-14]. Moreover, the industry is not the only factor to consider in formulating an academic program [15]; the development must engage many stakeholders [16] that also involves a number of activities [17] and sufficient budget allocation [18], which is a constraint for an underfunded education system such as the Philippines [19]. Adding to concern is the significant variation of indicators or models among countries at the academic program development level that do not contribute harmony and may be impractical for others to adopt $[20,21]$. Thus, this paper takes on that challenge by developing a universal framework for curriculum developers who are interested to establish an industry-aligned academic program regardless of the HEIs mission, vision and goals, and operational capacity and resources.

\section{RESEARCH METHOD}

\subsection{The IDAE framework}

The IDAE model model is a simple and universally applicable framework that attempts to reflect the actual critical variables or components that closely resemble reality in terms of academic program development. The acronym IDAE stands for Identify, Determine, Assess and Establish. The model is based on major components [22, 23] integrated and converted into transformational outlined-questions to initiate operational action. The first three components of the framework are represented by the circles labeled as "Identify", "Determine", and "Assess" in the funnel, as seen on Figure 1.

These components are concerned with examining the intellectual value and societal contribution, industry demand and societal interest, and capability or compliance of the academic institution in offering the proposed program, respectively. Each circle has an equivalent outlined-questions, which are significant inputs to the last component- Establish (E). The outlined questions are conditions, represented by the funnel and arrow that must be met before the "E" component is implemented. If at least one among the first three components is not satisfied, then the last component- "E" is not pursued. The model lays the groundwork for planning and developing degree programs organized.

The perspective of the IDAE framework only encompasses the external and internal analysis along a set of criteria given the institution and stakeholders. Here, work is completed when the proposed undergraduate program is determined industry-aligned or not. Thus, discussion on curriculum design from frame learning and teaching is not included in this paper.

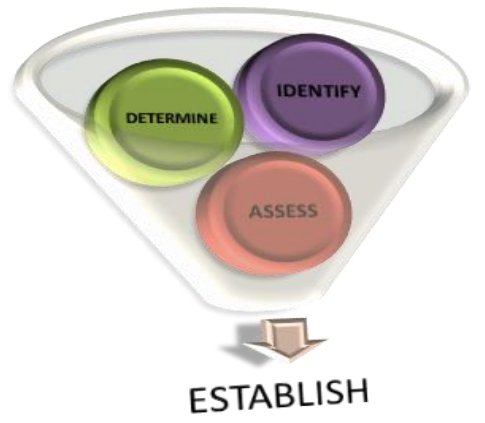

Figure 1. IDAE model

Int. J. Eval. \& Res. Educ. Vol. 9, No. 2, June 2020: 461 - 468 


\subsection{Data source and collection approach}

The data should come from three sources aligned along the IDAE outlined questions, namely: (1) companies with demand for the technology skills or academic program being proposed, (2) target market interest, and (3) the educational institution to offer the program. For the purposes of this paper, the research setting was carried out in the fifth district of Camarines Sur or simply Rinconada, which covers six municipalities (Nabua, Bula, Bato, Balatan, Buhi, and Baao), and one component city (Iriga). (1) Among the companies in the area, three BPOs, two supermarkets, and seven government offices participated in this study. Data were collected thru face-to-face and telephone interviews with the concerned HR officers. (2) There were 361 sampled from 3, 752 officially enrolled Grade10 students in the school year 2015-2016, participated by four private and seven public schools within Rinconada. Stratified random sampling was employed to ensure that the sample consisted of members from the target strata, for example the socioeconomic status. The instrument for the data collection was a one-page survey questionnaire that included basic demographic items, and course preferences distributed and collected within classroom sessions. (3) As with the last source, documents were collected from CSPC to assess the alignment of the new program's Program Educational Outcomes (PEO) with the CSPC's mission and vision, and evaluate the current status and compliance of CSPC against CHED memorandum order (CMO) 25 S.2015 [24] in terms of the required resources along faculty, library, and laboratory and physical facilities. PEO refers to the expected learning outcomes, competencies, and graduate attributes that programs are expected to attain from its graduates a few years after graduation.

Given the sample data source, the proportions of IT related job vacancies and currently employed IT-related positions of each company for the last three years were constructed to understand its underlying trendline. Identifying the trend can help quantitatively forecast the future event using linear regression Forecasting (LRF), for this purpose- next five years. LRF basically uses time series data to measure past values to predict future values [25]. THE LRF equation is represented by: $y=m x+b$, where $y$ is the past values to be calculated (dependent variable), or in this case, the number of IT-related positions employed by the companies per year, $m$ is the slope of the line, which equals the change in the $y$ value divided by the change in the $x$ value, $x$ is the given data point or the independent variable, in this case, it is the year, and $b$ is the $y$-axis intercept of the line.

To determine societal interest, multiple cross-tabular analysis was employed. Accordingly, the statistical significance of the associations was determined using Chi-square test with a five percent probability level given that the variables (societal interest) are completely independent of each other and has no association in offering Bachelor of Science in Information Systems (BSIS) at CSPC as the Null Hypothesis. On the other hand, data analysis was used to describe the compliance status of CSPC versus the standard CMO requirements along faculty, library, and laboratory and physical facilities. The results of the analysis were translated into a percentage data table.

\section{RESULTS AND DISCUSSION}

\subsection{Intellectual contribution}

The academic program development committee must firstly construct the PEO that shall address a valid educational skill and life-long learning purpose congruent with the mission statement of the concerned college or university. As depicted in Table 1, the PEO of the proposed BSIS program is grounded along the CSPC's mission statements to be demonstrated by its graduates three years after graduation.

Table 1. Relationship of BSIS's PEO to CSPC's mission statement

\begin{tabular}{|c|c|c|c|c|}
\hline \multirow{2}{*}{ PEO } & \multicolumn{4}{|c|}{ MISSION* } \\
\hline & 1 & 2 & 3 & 4 \\
\hline $\begin{array}{l}\text { 1. Apply knowledge of business processes, modeling, and social sciences to strategically } \\
\text { design, implement, deliver, and manage cost-effective IT-based solutions; }\end{array}$ & $\checkmark$ & & & \\
\hline $\begin{array}{l}\text { 2. Demonstrate ability to effectively communicate at a team level and the public at large; } \\
\text { 3. Exhibit exemplary behavior conscious of social and environmental responsibility } \\
\text { through active professional engagement; and }\end{array}$ & $\checkmark$ & & & $\checkmark$ \\
\hline 4. Engage in lifelong learning for personal and professional development. & & $\checkmark$ & $\checkmark$ & \\
\hline
\end{tabular}

This first step is most important since it directs and describes the connection of the course to career employment. It is essential for every academic program to have a clear account of what skills are expected of the course and what the institution is trying to achieve in providing it [26]. The committee must also ascertain 
that the developed PEOs meet all mission statements through a proposal in discussion with the concerned faculty members, stakeholders, academic council, and administrators. This way, administrators can properly allocate college resources adequately for the new program, potential employers can easily identify the skills graduates can offer after taking the course, while researchers can simply assess attainment of the PEO through evaluation [27].

\subsection{Industry demand}

Academic programs must respond to stakeholder needs. In agreement with this statement and Starodubtseva et al. [28], knowing the expected profile of the labor market needs improves the quality and relevance of the academic program. Thus, need is determined using labor market data. Figure 2 shows the prediction result on the demand for IT-related positions for the next five years using the raw data on the demand for BSIS graduates or any IT-related positions for the last three years of the industries around Rinconada and nearby cities and municipalities.

The distribution of the industry respondents included only companies or industries that demand IT-related employment opportunities. These companies have been identified based on the number of employment opportunities that called for Rinconada to accelerate its readiness to IT-related available jobs, such as BPO opportunities from notably call center activities (voice) to high-end undertakings, database management, animation and software development. Similarly, the identified group of supermarkets offered opportunities for individuals with skills for IT and management information system (MIS), graphic design, knowledge based-services to computer hardware servicing. Likewise, government offices also continue to demand IT-enabled services such as computer encoding, computer hardware servicing, and MIS services. Employment under the BPO industry was roughly 3,000 for the last three (3) years or nearly 96 percent of the total employment whereas a share of four percent in the same period for supermarket and government offices. The latter industries offer a very small percentage of job opportunities, however, promises steady up-trend employment. Moreover, factors affecting employment were not considered since the projection is through LRF, which uses only time series data.

It also illustrates the demand for IT-related positions (in terms of numbers reflected in the vertical axis) of the three leading industries in Rinconada - BPO, government offices and supermarkets from 2013-2015 (reflected in the horizontal axis) plotted or marked using scatter plot. The forecast essentially reflects that each dependent variable will increase its trend into the future. Most significant growth is predicted in the BPO industry. Substituting the values in the linear regression equation, values for $\mathrm{x}$ such as 2020 (five-year forecast from 2016), we can predict that IT-related jobs are expected to grow by $84.92 \%$ up to 2020 , creating 1, 803 new jobs in the BPO sector. A similar prediction holds for government offices and supermarkets. Looking at the equation on the graphical presentation for government offices, it is found that by the year 2020, employment generation for IT-related positions will be doubled by 100 percent. While the supermarket industry was the least generator of employment with a 76.92 percent increase.

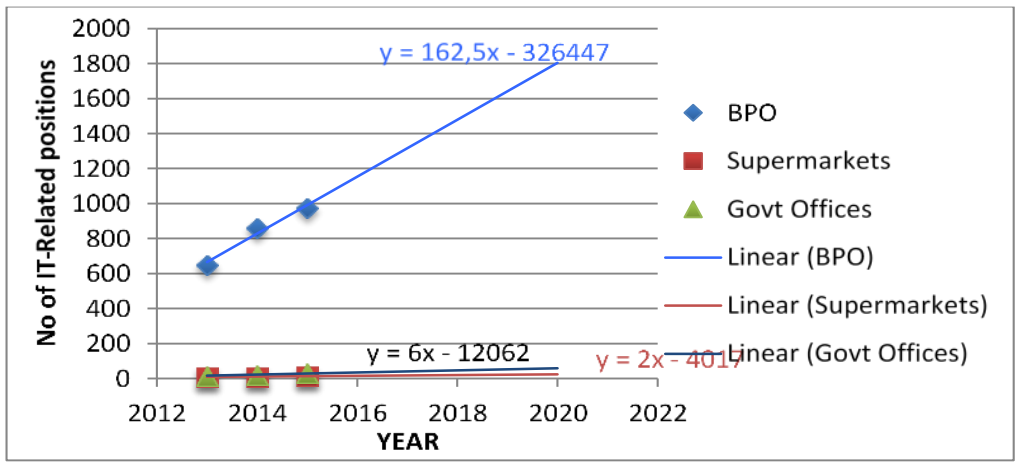

Figure 2. Five-year demand forecast for IT-related positions

\subsection{Social interest}

Student perception and attitude about a career usually affect their choice in selecting a college course. Across investigation studies, interest was indicated as the major significant factor that influenced course choice [29, 30]. However, most recent research also probed that socio-economic status has an essential relevance to students' choice of career to study [31]. Of significance in this regard, special 
attention to socio-economic status was deemed a necessary factor in this investigation. Hence, students' perception regarding socio-economic status on choice of SHS track was examined. SHS in the Philippines include career tracks, namely: Academic (Acad), Technical-Vocational livelihood (TechVoc), Arts and Design (Arts), and Sports. The Academic track consists of courses for the most common college courses, such as engineering, information technology, business management, and the sciences. Table 2 shows the actual count and percentage of the Grade 10 student-respondents' preferred track.

Table 2. Observed frequencies of grade 10 chosen track

\begin{tabular}{cccccc}
\hline SocioEconomic Status & Acad & TechVoc & Arts & Sports & $\mathrm{N}$ \\
\hline Below 10,000 & $108(29.92 \%)$ & $21(5.82 \%)$ & $3(0.83 \%)$ & $9(2.49 \%)$ & $141(39.06 \%)$ \\
$10,001-20,000$ & $58(16.07 \%)$ & $28(7.76 \%)$ & $5(1.39 \%)$ & $3(0.83 \%)$ & $94(26.06 \%)$ \\
$20,001-30,000$ & $42(11.63 \%)$ & $13(3.6 \%)$ & $9(2.49 \%)$ & $1(0.28 \%)$ & $65(18.01 \%)$ \\
$30,001-40,000$ & $19(5.26 \%)$ & $7(1.94 \%)$ & $8(2.22 \%)$ & $1(0.28 \%)$ & $35(9.7 \%)$ \\
40,001- 50,000 & $9(2.49 \%)$ & $1(0.28 \%)$ & 0 & 0 & $10(2.77 \%)$ \\
Above 50,001 & $4(1.11 \%)$ & 0 & $1(0.28 \%)$ & 0 & $5(1.39 \%)$ \\
Undecided & $11(3.05 \%)$ & 0 & 0 & 0 & $11(3.05 \%)$ \\
TOTAL & $251(69.53 \%)$ & $70(19.39 \%)$ & $26(7.20 \%)$ & $14(3.88 \%)$ & 361 \\
\hline
\end{tabular}

Among Grade 10 students $69.53 \%$ regardless of their socioeconomic status, planned to choose Academic track, where only $1.11 \%$ of those with high socioeconomic status or family income exceeds 50,000 pesos a month, in comparison with $29.92 \%$ of those with very low socioeconomic status or family income is below 10, 000 pesos a month, which is within the poverty threshold, when they enroll for SHS. Likewise, $19.39 \%$ of all Grade 10 students planned to choose the Technical-Vocational track where $7.76 \%$ of those belong to the low socioeconomic status or family income does not exceed 20,000 pesos per month, followed by $5.82 \%$ Grade 10 students with very low socioeconomic status or family income is below 10, 000 pesos a month. Merely $7.20 \%$ planned to choose Arts and Design track, however, $2.49 \%$ of those belong to the lower middle socioeconomic status or family income does not exceed 30,000 per month. The Sports track with rather very low percentage of $3.88 \%$ is the least chosen track among Grade 10 student-respondents where most students are with very low socioeconomic status or the family income is below 10, 000 pesos a month. On the other hand, a number of Grade 10 student-respondents were undecided of their socioeconomic status with a percentage of $3.05 \%$ as against the total sample population. All Grade 10 student-respondents with undecided level status chose the Academic track.

It is also observed that $39.06 \%$, regardless of the chosen track, belong to the very low socioeconomic status or family income is below 10,000 pesos a month followed by $26.06 \%$ or Grade 10 students with low socioeconomic status or family earnings does not exceed 20,000 per month, however, both appear to prefer Academic track with a subtotal percentage of $45.99 \%$ or roughly half of the total Grade 10 students who chose the said track. Only a small proportion of $2.77 \%$ and $1.39 \%$ of the Grade 10 studentrespondents belonged to the Upper middle or family income not more than 50,000 a month and High socioeconomic status or family income more than 50, 000 per month, respectively. Both statuses chose the Academic track as their preferred track for SHS with $2.49 \%$ and $1.11 \%$ rate. It is evident that a large percentage of Rinconada's future college students belonged within very low- to lower middle socioeconomic status with a subtotal percentage of $83.13 \%$. The results of the cross-tabular analysis presented in Table 3 clearly indicate that, regardless of the socioeconomic status, the Academic track appears to be the most chosen track. Thus, by these findings, it can rightfully be concluded that the greater the preference of Grade 10 students for Academic track the greater the chances of enrollees on IT-related courses.

Table 3. Expected frequencies of grade 10 chosen track

\begin{tabular}{lccccc}
\hline $\begin{array}{c}\text { SocioEconomic } \\
\text { Status }\end{array}$ & Acad & TechVoc & Arts & Sports & N \\
\hline Below 10,000 & 98.04 & 27.34 & 10.16 & 5.47 & 141 \\
10,001- 20,000 & 65.36 & 18.23 & 6.77 & 3.65 & 94 \\
20,001- 30,000 & 45.19 & 12.60 & 4.68 & 2.52 & 65 \\
30,001- 40,000 & 24.34 & 6.79 & 2.52 & 1.36 & 35 \\
40,001- 50,000 & 6.95 & 1.94 & 0.72 & 0.39 & 10 \\
Above 50,001 & 3.48 & 0.97 & 0.36 & 0.19 & 5 \\
Undecided & 7.65 & 2.13 & 0.79 & 0.43 & 11 \\
TOTAL & 251 & 70 & 26 & 14 & 361 \\
\hline
\end{tabular}


Another critical factor in the process is whether to reject or accept the null hypothesis. The test for interdependence on the socio-economic status of Grade 10 students that chose Academic and TechVoc track in offering BSIS at CSPC perhaps is the most interesting. Given the expected frequencies in Table 3 and based on a $5 \%$ confidence level, the chi-square test result is 0.000551592 , which means that the association of the socioeconomic status and the chosen SHS track in offering BSIS at CSPC is profoundly significant. Therefore, the null hypothesis is rejected.

\subsection{Institutional capability}

The availability of resources is associated to the operational capacity of an institution in offering the new program. Thus, it is essential that HEIs follow the minimum standards mandated by the governing accrediting agencies as applicable. For example, the indicators presented in Table 4 are the minimum requirements stipulated in the CHED CMO S2015. In the Philippines, HEIs must be fully compliant with the requirement guidelines of CHED to secure a Certificate of Program Compliance (COPC). The COPC is a document that ascertains the readiness and capability of the HEIs to operate a specific academic program. Thus, CSPC, through the College of Computer Studies (CCS) and the College library, considered each of these indicators during the interview and document collection. Table 4 gives a further breakdown of the eight-resource categories as per indicated in CMO 25. S2015 Section 14 [24].

The data in Table 4 essentially displays the full compliance of CSPC in all indicators per criterion from 4.1.1.1- Faculty requirement down to 4.1.3.3- Laboratories and Physical facilities. This suggests that starting a new academic program requires careful thinking and consideration of resource issues, such as faculty support, and classroom and technology capacity. In doing so, opportunities to maximize efficiency and utilization increase the potential for success of the program.

Table 4. CSPC compliance per CMO 25 s.2015

\begin{tabular}{|c|c|}
\hline CMO Requirement & CSPC Compliance \\
\hline \multicolumn{2}{|c|}{ 4.1.1.1 Faculty Composition } \\
\hline A. Three (3) full time faculty members per program & $\begin{array}{c}\text { Compliant. } 100 \% \text { or } 15 \text { Full-time faculty members for the existing } \\
\text { three programs (IT, BLIS, and CS) }\end{array}$ \\
\hline $\begin{array}{l}\text { B. There shall be a faculty member with industry } \\
\text { experience within the last two (2) years. }\end{array}$ & Compliant. $26.6 \%$ or $4 / 15$ faculty members. \\
\hline C. Doctorate degrees in CS, IT, IS or allied fields & Compliant. $13.33 \%$ or $2 / 15$ with doctorate degree. \\
\hline D. Actively do research and development work & $\begin{array}{c}\text { Compliant. } 26.6 \% \text { or } 4 / 15 \text { regular faculty members actively do } \\
\text { research work. }\end{array}$ \\
\hline $\begin{array}{l}\text { E. Actively participate in computing related professional } \\
\text { organizations }\end{array}$ & $\begin{array}{l}\text { Compliant. } 100 \% \text { or } 15 / 15 \text { regular faculty members are active } \\
\text { members in the computing-related professional organizations. }\end{array}$ \\
\hline \multicolumn{2}{|c|}{ 4.1.1.2 Faculty Support } \\
\hline $\begin{array}{l}\text { A. One (1) computer for every three (3) full-time } \\
\text { equivalent faculty members and one (1) for every } \\
\text { administrator. }\end{array}$ & $\begin{array}{l}\text { Compliant. All } 15 \text { regular faculty members were provided with } \\
\text { serviceable laptops and one common workstation for COS. }\end{array}$ \\
\hline B. Consultation area for student and faculty. & $\begin{array}{l}\text { Compliant. A dedicated space for consultation is available located } \\
\text { inside the Faculty Lounge. }\end{array}$ \\
\hline \multicolumn{2}{|r|}{ 4.1.2.1 Librarian } \\
\hline $\begin{array}{l}\text { At least one (1) librarian/ staff for every five hundred } \\
\text { (500) students or fraction thereof. }\end{array}$ & $\begin{array}{l}\text { Compliant. Nine library staff composed of five licensed librarians and } \\
\text { four staff members for } 4,200+\text { students. }\end{array}$ \\
\hline \multicolumn{2}{|c|}{ 4.1.2.2 Book Collection } \\
\hline $\begin{array}{l}\text { A. At least five (5) titles per professional course and at } \\
\text { least one (1) of which has been published within the last } \\
\text { five (5) years. There should be one (1) volume for every } \\
\text { ten (10) students enrolled. }\end{array}$ & $\begin{array}{c}\text { Compliant. } \\
\text { No. of core and professional subjects }=39 \\
\text { Total no. of titles }=213 \\
\text { Total no. of volume }=594\end{array}$ \\
\hline B. 2 publications per program of up-to-date computer & Compliant. \\
\hline $\begin{array}{l}\text { magazines, journals, and periodicals that are published } \\
\text { locally and internationally. }\end{array}$ & $\begin{array}{l}\text { Current subscriptions with Journal of Database Mngt., Phil. and } \\
\text { Computing Journal, and Phil. Info. Tech. }\end{array}$ \\
\hline C. Internet terminals for access & Compliant - with eleven dedicated computer terminals Internet access \\
\hline D. Access to electronic library materials & and e-library materials \\
\hline E. Provide Learning Commons & $\begin{array}{c}\text { Compliant. The library houses isolated learning commons for faculty } \\
\text { and students }\end{array}$ \\
\hline \multicolumn{2}{|c|}{ 4.1.2.3 Space Requirement } \\
\hline $\begin{array}{l}\text { Seating capacity of at least five percent (5\%) of the total } \\
\text { students enrolled and minimum floor area of at least two } \\
\text { (2) sq.m per set }\end{array}$ & Compliant. 806.3 sq.m library floor area. \\
\hline \multicolumn{2}{|c|}{ 4.1.3.1 Classroom Requirements } \\
\hline $\begin{array}{l}\text { One (1) classroom per hundred fifty (150) students } \\
\text { enrolled } \\
\text { Table 5. (Cont.) CSPC Cor }\end{array}$ & $\begin{array}{l}\text { Compliant or six rooms (Academic rooms 1-5 and DH 217) for } 751 \\
\text { students (Total count of ICT students only) } \\
\text { pliance per CMO 25S.2015 requirement }\end{array}$ \\
\hline
\end{tabular}

Int. J. Eval. \& Res. Educ. Vol. 9, No. 2, June 2020: 461 - 468 
Table 4. CSPC compliance per CMO 25 s.2015 (continued)

\begin{tabular}{|c|c|}
\hline CMO Requirement & CSPC Compliance \\
\hline \multicolumn{2}{|c|}{ 4.1.3.2 Laboratory Requirement } \\
\hline $\begin{array}{l}\text { A. Terminals should be at least } 1 / 5 \text { of the total number } \\
\text { of computing students. Laboratory class should be } 1: 1 \\
\text { ratio }\end{array}$ & $\begin{array}{l}\text { 100\% compliant or } 3 \text { laboratories (ITLab1, ITLab2, and CSLab) for } \\
751 \text { students }\end{array}$ \\
\hline $\begin{array}{l}\text { B. Minimum of } 4 \mathrm{Mbps} \text { Internet access for the students } \\
\text { and faculty at the laboratories }\end{array}$ & $\begin{array}{l}\text { Compliant. All computer laboratories have a dedicated Internet } \\
\text { connection. }\end{array}$ \\
\hline C. Internet terminals for access & $\begin{array}{l}\text { Compliant. All computer terminals at the laboratories have Internet } \\
\text { access. }\end{array}$ \\
\hline \multicolumn{2}{|r|}{ 4.1.3.3 Visual Facilities } \\
\hline $\begin{array}{l}\text { Every lecture rooms and laboratory must be equipped } \\
\text { with projectors or large display for demonstrations. }\end{array}$ & $\begin{array}{l}\text { Compliant. One interactive projector at ITLab2, and multimedia } \\
\text { projectors installed each at ITLab1, and CSLab. } \\
\text { 60-65" LED TV installed at rooms 1-4 of the Academic Building } 1 .\end{array}$ \\
\hline
\end{tabular}

\subsection{IDAE summary result}

The results presented in Table 5 are the summary findings previously described according to the IDAE framework components. Following the aim of the framework, the first three components shall be analyzed to establish a final decision for the last component. In this new framework, the results of the first three components are the major consideration in making a recommendation for the last component. Considering the Result/ Decision column for the Establish component, the decision indicates "Best to pursue the proposed academic program"- BSIS in CSPC. This suggests that the HEI's intellectual contribution and availability of resources is substantial to offer the program. Likewise, the proposed program is also responsive to the industry demand to fill the immediate need for experts, and recognizes the emerging societal needs in terms of interest and socio-economic value hence the recommendation. The framework also highlights its universal design to curb the shortcomings of the current program development practices indicated in $[20,21]$. This implies that regardless of the HEI's mission and distinctive features, commonalities of policies, standard and guidelines in developing an academic program is possible.

Table 5. IDAE components vs results

\begin{tabular}{|c|c|c|}
\hline Component & Result/ Decision & Remarks \\
\hline $\begin{array}{l}\text { IDENTIFY. What is the intended intellectual } \\
\text { value and societal contribution of the proposed } \\
\text { or revised program to its constituents }\end{array}$ & Compliant & $\begin{array}{l}\text { PEO was constructed congruent to the CSPC's mission } \\
\text { statement. It is also recommended that the PEOs be aligned } \\
\text { with the department's goals and objectives } \\
\text { (through a matrix). }\end{array}$ \\
\hline $\begin{array}{l}\text { DETERMINE. What is the present industry } \\
\text { demand and societal interest for } \\
\text { the proposed program? }\end{array}$ & Compliant & $\begin{array}{l}\text { Employment generation for IT-related positions will be } \\
\text { doubled by } 100 \text { percent starting } 2020 \text { per forecast equation } \\
\text { result. Meanwhile, chi-square test result suggests that the } \\
\text { offering of BSIS at CSPC is profoundly significant given } \\
\text { the considerable association of the socioeconomic status } \\
\text { and the chosen SHS track of the student-respondents. }\end{array}$ \\
\hline $\begin{array}{l}\text { ASSESS. What is the HEI's capability or status } \\
\text { to offer the program respective to the Policies, } \\
\text { Standards, and Guidelines (PSG) recommended } \\
\text { by the Commission for Higher Education? }\end{array}$ & Compliant. & $\begin{array}{l}\text { All eight-reseouce categories as per indicated in CMO } 25 . \\
\text { S2015 Section } 14 \text { was complied with. }\end{array}$ \\
\hline
\end{tabular}

\section{CONCLUSION}

The proposed IDAE framework practically gives direction to the degree program development process of CSPC. Findings for the first three components points to the conclusion that it is viable to establish a BSIS program in CSPC in terms of institutional contribution, industry demand and societal interest, and institutional capability.

Generally, because the framework used universal and actual components that closely resemble reality in terms of degree program development, the implementation turned out to be easy and authentic. However, findings also reveal that there are several significant opportunities for the framework to improve its suitability and quality. First, additional theoretical justifications to the relevance of the selected components in terms of academic program development must be undertaken to clearly define the model performance. Second, provide more empirical evidence to establish the effectiveness and appropriateness of the IDAE framework. 


\section{REFERENCES}

[1] Philippine Statistics Authority, "2017 Annual Labor and Employment Status," 2017.

[2] W. Depasupil, "1 million graduates face job-skill mismatch," The Manila Times, 2017. [Online] Available: http://www.manilatimes.net/1-million-graduates-face-job-skill-mismatch/317111/

[3] G. Montt, "The causes and consequences of field-of-study mismatch: An analysis using PIAAC," OECD Soc. Employ. Migr. Work. Pap., vol. 157, p. 88, 2015.

[4] Philippine Statistics Authority, "Employment Rate in April 2019 is Estimated at 94.9 Percent," 2019. [Online]. Available: https://psa.gov.ph/content/employment-rate-april-2019-estimated-949-percent. [Accessed: Nov 2019].

[5] Department of Labor and Employment, "Project JobsFit: The DOLE 2020 Vision," 2010.

[6] A. C. Orbeta Jr., K. G. Gonzales, and S. F. S. Cortes, "Are higher education institutions responsive to changes in the labor market," Philipp. Inst. Dev. Stud., vol. 8, no. March, pp. 1-35, 2016.

[7] A. Ghani, "Bridging the gap between industry and higher education demands on electronic graduates' competencies," IOSR J. Electr. Electron. Eng., vol. 8, no. 1, pp. 63-68, 2013.

[8] O. Kupets, "Education-job mismatch in Ukraine: Too many people with tertiary education or too many jobs for low-skilled?," J. Comp. Econ., vol. 44, no. 1, pp. 125-147, Feb. 2016.

[9] Commission on Higher Education, "Distribution of Higher Education Institutions by Institution Type: AY 201617," Metro Manila, 2017.

[10] A.-M. Zamfir, M. M. Matei, and E. O. Lungu, "Influence of education-job mismatch on wages among higher education graduates," Procedia - Soc. Behav. Sci., vol. 89, pp. 293-297, Oct. 2013.

[11] B. Shewakena Tessema, "University-industry collaboration in curriculum development: analysis of banking and finance graduates' attributes from educators and industries perspective," Educ. J., vol. 6, no. 2, pp. 87, 2017.

[12] Nepomuceno, "Bachelor of arts in broadcasting: A research- based industry demand analysis," 2005.

[13] S. Elliot and M. Joppe, "A case study and analysis of e-tourism curriculum development," J. Teach. Travel Tour., vol. 9 , no. 3/4, pp. 230-247, 2009.

[14] I. A. Buckley and H. Narang, "A study: exploring the feasibility of developing a computer science online degree program at Tuskegee University," High. Educ. Stud., vol. 4, no. 3, pp. 48-57, 2014.

[15] Katja Fleischmann, "Industry-driven design education: How much should market/industry dictate pedagogy?" in agIdeas Research: Design for Business, 1st ed., Melbourne: agIdeas, pp. 76-95, 2012.

[16] M. A. Alsubaie, "Curriculum development: Teacher involvement in curriculum development," J. Educ. Pract. 10, vol. 7, no. 9, pp. 106-107, 2016.

[17] A. Wiek, L. Withycombe, and C. L. Redman, "Key competencies in sustainability: A reference framework for academic program development," Sustain. Sci., vol. 6, no. 2, pp. 203-218, 2011.

[18] D. S. Martin, P. S. Saif, and L. Thiel, "Curriculum development: Who is involved and how?" Educ. Leadersh., vol. 44, no. 4, pp. 40-48, 1987.

[19] Bjorn Biel M. Beltran, "Education reform and the Philippine economy," BusinessWorld, 2019. [Online]. Available: https://www.bworldonline.com/education-reform-and-the-philippine-economy [Accessed: 08-Apr-2020].

[20] A. Hussain, A. H. Dogar, M. Azeem, and A. Shakoor, "Evaluation of curriculum development process," Int. J. Humanit. Soc. Sci., vol. 1, no. 14, pp. 263-271, 2011.

[21] A. Muradov, "A model of academic program review for program improvement," University of Massachusetts, 2001.

[22] R. Emans, "A proposed conceptual framework for curriculum development," J. Educ. Res., vol. 59, no. 7, pp. 327-332, 1966.

[23] D. Silva, "Components in program development," Am. J. Occup. Ther., vol. 30, no. 9, pp. 568-575, 1976.

[24] Commission on Higher Education [CHED], Revised Policies, Standards, and Guidelines for BSCS, BSIS, and BSIT programs, p. 57, 2015.

[25] R. Adhikari and K. R. Agrawal, “An introductory study on time series modeling and forecasting," L. Lambert Acad. Publ. Ger., 2013.

[26] Commission on Higher Education [CHED], "Policy-standard to enhance quality assurance (QA) in Philippine Higher Education through outcomes-based and typology-based QA.” pp. 1-36, 2012.

[27] N. E. A. Basri et al., "An evaluation of programme educational objectives and programme outcomes for civil engineering programmes," in Procedia - Social and Behavioral Sciences, vol. 18, pp. 56-64, 2011.

[28] D. V. Starodubtseva, O. M. Zamyatina, and Y. O. Goncharuk, "Curriculum design and development of master's educational programs in IT area (through the example of international development of master programs "Applied computing' and 'Product life cycle technological process efficiency' of TEMPUS SUCCESS and ACES pro," in Proceedings of 2015 International Conference on Interactive Collaborative Learning, pp. 393-396, 2015.

[29] W. Mata-López and S. Tobón, "Analysis of factors associated to the enrollment and demand of computing-related careers," Soc. Sci., vol. 8, no. 1, pp. 1, Dec. 2018.

[30] J. M. Curran and D. E. Rosen, "Student attitudes toward college courses: An examination of influences and intentions," J. Mark. Educ., vol. 28, no. 2, pp. 135-148, 2006.

[31] K. Leppel, M. L. Williams, and C. Waldauer, "The impact of parental occupation and socioeconomic status on choice of college major,” J. Fam. Econ. Issues, vol. 22, no. 4, pp. 373-394, 2001. 